\title{
A root exudates based approach to assess the long-term phytoavailability of metals in biosolids-amended soils
}

\author{
Bon-Jun Koo ${ }^{a}$, Weiping Chen ${ }^{b, *}$, Andrew C. Chang ${ }^{c}$, Albert L. Page ${ }^{c}$, Thomas C. Granato ${ }^{d}$, \\ Robert H. Dowdy ${ }^{\mathrm{e}}$ \\ ${ }^{a}$ Department of Natural and Mathematical Sciences, California Baptist University, Riverside, CA 92504, USA \\ ${ }^{\mathrm{b}}$ State Key Lab of Urban and Regional Ecology, Research Center for Eco-Environmental Sciences, Chinese Academy of Sciences, Beijing 100085, China \\ ${ }^{\mathrm{c}}$ Department of Environmental Sciences, University of California, Riverside, CA 92521, USA \\ ${ }^{\mathrm{d}}$ Metropolitan Water Reclamation District of Greater Chicago, Chicago, IL 60611, USA \\ e Department of Soil, Water and Climate, University of Minnesota, St Paul, MN 55108, USA \\ A new approach based on root exudates extraction was developed to assess the phytoavailability of metals in biosolids-amended soils.
}

\section{A R T I C L E I N F O}

\section{Article history:}

Received 6 January 2010

Received in revised form

12 May 2010

Accepted 14 May 2010

\section{Keywords:}

Phytoavailability

Model

Heavy metal

Biosolids-amended soil

Rhizosphere

Root exudates

\begin{abstract}
A B S T R A C T
Organic acids present in the rhizosphere of growing plants are widely recognized to be responsible for dissolving the solid phase metals in the soil and making them available for plant absorption. We proposed a root exudates-based model to assess the long-term phytoavailability of metals in biosolidsamended soils. The phytoavailability of biosolids-borne metals was defined in terms of a capacity factor and an intensity factor. The plant available metal pool, $C_{0}$ (capacity factor, $\mathrm{mg} \mathrm{kg}^{-1}$ ), can be estimated by fitting the successive organic acids extraction data to an exponential decay kinetic equation. The field metal removal rate, $k$ (intensity factor, $\mathrm{yr}^{-1}$ ), can be estimated from the successive extraction-based metal release rate through an effective annual organic acid production in the rhizosphere which was found to be characteristic of plant species. The protocol was successfully used to assess the long-term phytoavailability of metals in biosolids-amended soil from two biosolids land application sites.
\end{abstract}

(c) 2010 Elsevier Ltd. All rights reserved.

\section{Introduction}

When biosolids are land applied, significant amounts of metals may be introduced into the receiving croplands. From the soils, the potentially harmful metals may inadvertently enter the human food chain. As the harvested plants typically absorb a small fraction of those applied, it may affect the plant uptake long after the operations ceased (Brown et al., 1996; McGrath et al., 2000). The availability of a soil-borne metal to plants customarily is defined by soil-based measurements, plant-based measurements, or a combination of both. For plant-based measurements, the availability is represented simply by the amount of metals that the plant absorbs or the concentrations in the harvested plant tissue. However, plants absorb a rather small fraction of the soil borne metals each season. Outcomes from one or two harvests do not shed much light on overall availability of the metals. In soil-based measurements, the total metal contents of the soil or fractional amounts extracted by

\footnotetext{
* Corresponding author.

E-mail address: wpchen@rcees.ac.cn (W. Chen).
}

chemical reagents employed under preset conditions are used as indicators of plant availability of soil metals. One single extraction frequently does not capture all of the available metals and the measurement does not reflect the temporal trend of actual amounts absorbed by plants (Wang et al., 2004). Kim and McBride (2006) found that the amounts of metals extracted by the sequential extraction procedures were strongly dependent on the order of extraction, the type of reagents and the nature of the individual metals. While the plant-based measurements often are linearly correlated to the corresponding soil-based measurements under certain cases (McBride et al., 2004; Guerra et al., 2007; Torri and Lavadoa, 2009), it is often hard to apply the empirical correlations to other cases (O'Connor, 1988). With a large data set, Menzies et al. (2007) concluded that trace metal concentrations determined by complexing agents such as the widely used DTPA and EDTA extractants or acid extractants such as $0.1 \mathrm{MHCl}$ and the Mehlich 1 extractant are poorly correlated to plant phytoavailability. So far, there is no agreement in the literature as to which extractant most accurately estimates the phytoavailability of trace metals in soils.

Growing plants generally absorb nutrients and other substances such as metals through root extraction of the soil solutions. As the 
majority of the introduced metals with land application of biosolids tend to be discrete particulates intermingled with masses of soil aggregates (Candelaria and Chang, 1997), the metals in solution phase are likely present in the vicinity of metal-containing particulates and their transport through soils to the plant root would be short-range mass transfers. Therefore, plant absorption of biosolids-borne metals would mainly take place at the root-soil interface, i.e. the rhizosphere where root exudates play important roles in dissolving and making metals available for plant absorption (Hinsinger, 1998; Philippe et al., 2006).

Plant roots exude a variety of soluble substances. Among them, organic acids are by far the most abundant and the most reactive with metals (Laheurte et al., 1990; Pomilio et al., 2000). Researchers have found that low-molecular-weight organic acids in the rhizosphere are capable of forming complexes with metal ions in solution and thus enhance the metals' mobilization and uptake by plants (Mench and Martin, 1991; Awad et al., 1994; Krishnamurti et al., 1997; Veeken and Hamelers, 1999; Chen et al., 2003; Gao et al., 2003; Hu et al., 2007; Luo et al., 2008). Feng et al. (2005) showed that the extractable amount of $\mathrm{Cr}, \mathrm{Cu}, \mathrm{Zn}$ and $\mathrm{Cd}$ by the root exudes correlated significantly with the metal content of barley roots, while the extractable metals identified by DTPA, EDTA, $\mathrm{CaCl}_{2}$ and $\mathrm{NaNO}_{3}$ methods exhibited relatively poor or no correlation with the metal content of barley roots. They concluded that the rhizosphere-based method is the most robust approach for evaluation of bioavailability of metals in soil to barley. Chen et al. (2008) demonstrated that plant uptake of biosolids-borne metals was inversely proportional to the particle sizes of the biosolids. When the inputs remained equal, the smaller particle size fraction would yield larger number of particles thus more surface area for rootbiosolids interactions in the rhizosphere.

Typically, the rhizosphere consists of the 1 to $5 \mathrm{~mm}$ layer of soils surrounding the root cylinder (Tao et al., 2003; Chaignon et al., 2009). As such in a given growing season, all of the metals containing particles in the soil may not be under the influence of organic acids in the rhizosphere. Over time, however, all of the metal containing particles in the growth medium will be exposed to the influence of the rhizosphere. Availability of biosolids-borne metals must account for not only the plant uptake in one growing season but also the total amounts available over time. In this regard, neither the soil-based source assessment nor the plant-based end product measurements are able to delineate the true nature of the potential plant available metal pool of a soil. To assess the availability of metals to plants in the biosolids-receiving soils, the rate at which the biosolids-borne trace element is absorbed by the plant and the total amounts of plant available trace elements in biosolidsamended soils must be addressed. The former describes the plant uptake for a given time period such as one growing season. The latter defines the total available trace element pool of the receiving soil. Together, they track the time dependent changes of plant available trace element pool and uptake of plants over time.

In this paper, a new approach based on root exudates extraction is developed and tested to describe the availability of metals in biosolids-amended soils.

\section{Materials and methods}

\subsection{Model conception}

In the rhizosphere, the biosolids-borne metals are mainly present in solid forms and are not readily available to the growing plants. The dissolution by the root exudates is a significant pathway through which the plants absorb metals from biosolids-amended soils. We hypothesize that the phytoavailable metals in biosolids-amended soils can be determined by amounts of metals dissolved by root exudate derived organic acids in the rhizosphere. The metal uptake by plants is determined by the kinetics of metal release into solution by organic acids. In this manner, the phytoavailability of biosolids-borne metals may be defined in terms of a capacity factor (i.e. organic acids-extractable metals in soils), which describes the plant-available metal concentration in biosolids-amended soil and an intensity factor (i.e. the rate at which metals may be dissolved by organic acids), which indicates the rate at which metals will be absorbed by plants.

After the termination of land application of biosolids, the available metal pool of the soils should be gradually decreased with each crop harvest as metals were absorbed by plants and removed from the soils along with the harvested crop. Assuming the rate of absorption is proportional to the remaining available metals in the soil, mathematically, the phytoavailability of the biosolids-borne metals may be defined by the following equation:

$M_{t}=C_{0} e^{-k t}$

where $M_{t}$ represents the amounts of metal removed by crops ( $\mathrm{mg} \mathrm{kg}^{-1}$ soil) at time $t$ (year), $C_{0}$ is the capacity factor representing the labile metal pool of the biosolidsamended soils ( $\mathrm{mg} \mathrm{kg}^{-1}$ soil) and $k$ is the intensity factor representing the rate that metals in the biosolids-amended soils are absorbed by plants (year ${ }^{-1}$ ). Equation (1) may also be written in terms of the cumulative metal removal by the plant harvests, $M_{\mathrm{C}}\left(\mathrm{mg} \mathrm{kg}^{-1}\right.$ soil $)$ as:

$M_{C}=C_{0} \times\left(1-e^{-k t}\right)$

The plant available metal pool of biosolids-amended soils, $C_{0}$, may be determined as the total root exudate soluble metals in the soil. One time extraction may not dissolve all of the root exudate extractable metals in the soils. The biosolidsamended soils should be extracted multiple times to establish the pattern by which the metals might be successively removed. Assuming an exponential decay model, the cumulative removal by the successive extractions may be shown mathematically as:

$M_{q}=a \times\left(1-e^{-b q}\right)$

where $M_{q}$ represents the cumulative metal removed $\left(\mathrm{mg} \mathrm{kg}^{-1}\right)$ following successive extractions using $q$ volumes of synthetic organic acid (mole of $\mathrm{COO}^{-} \mathrm{kg}^{-1}$ soil), $a$ is the total extractable metal $\left(\mathrm{mg} \mathrm{kg}^{-1}\right)$ and by definition equals $C_{0}, b$ is a constant denoting the rate of metal release ( $\mathrm{kg}$ soil per mole of $\mathrm{COO}^{-}$). In this way, total phytoavailable metal, $C_{0}$, may be obtained by the non-linear regression analysis of the successive extraction data.

The two metal release rates, $b$ which is the organic acid volume based metal release rate constant of the successive extractions and $k$ which is the time based metal removal rate constant from plants grown in the field, may be reconciled by parameter, $A$, which represents the effective annual rhizosphere organic acids production factor of the soil with the unit of moles of organic acids per kg of soil per year (mole $\mathrm{COO}^{-} \mathrm{kg}^{-1} \mathrm{yr}^{-1}$ ). The time $(t, \mathrm{yr}$ ) for plants in the field to produce an equivalent of $q$ volume of organic acids can obtained as:

$t=q / A$

Combining Equations (3) and (4) and letting $M_{q}=M_{c}$, the field based metal uptake coefficient, $k$, is mathematically related to the metal release rate constant of the successive extraction, $b$, through the effective field organic acid production, $A$ :

$k=b \times A$

\subsection{Test data}

Data obtained from two long-term biosolids land application sites were involved in testing of the model, namely, the Fulton County Land Reclamation Site of the Metropolitan Water Reclamation District of Greater Chicago (designated as MWRDGC hereafter) and the Rosemont Experiment Station of the University of Minnesota (designated as UM hereafter).

The biosolids application fields at MWRDGC were established in 1973 on a calcareous mine spoil and each year corn was planted and harvested. Detailed information about the field plots were given by Pietz et al. (1982). The three selected biosolids application fields (Fields 19, 21, and 23) received comparable total biosolids mass loadings of $522-710 \mathrm{Mg} \mathrm{ha}^{-1}$ dry weight from 1974 to 1984 . From 1984 through 1997, these fields did not receive any biosolids application and corn planting and harvesting continued annually.

At the UM site, dewatered waste activated biosolids were applied on experimental plots at rates of $0,20,40$, and $60 \mathrm{Mg} \mathrm{ha}^{-1} \mathrm{yr}^{-1}$ from 1977 through 1979. The four biosolids treatments were designated as control, low, medium and high treatments. There were four replicates for each treatment. The plots remained in the three-year rotation of corn (Zea mays L.), oat (Avena sativa L.), and alfalfa (Medicago sativa L.) where biosolids replaced the fertilizer applications. The description of the experimental set up and the results were summarized in Dowdy et al. (1991). Following the termination of biosolids application, the plots were continuously cultivated with corn annually until 1984.

Following the end of biosolids application, the metal uptake by corn was tracked for 12 years (1984-1997) at the MWRDGC and 7 years (1978-1984) at the UM. At each season, corn was sampled at the hard dent stage of development, dried at $70^{\circ} \mathrm{C}$, 
and ground to pass a 20-mesh sieve and soil samples were taken at the same time, air dried and ground. We obtained the archived soil and plant tissue samples for the testing. The accumulative metal uptake of these periods might be calculated based on the biomass yields and corresponding metal content of harvested plant tissues.

\subsection{Plant and soil sampling and analysis}

Metals in the plant tissues were extracted with concentrated $\mathrm{HNO}_{3}+\mathrm{H}_{2} \mathrm{O}_{2}$ and metals in the soil were dissolved with $\mathrm{HNO}_{3}+\mathrm{HF}$ both using a CEM Mars 5 microwave digestion system. Copper, $\mathrm{Ni}$, and $\mathrm{Zn}$ in the extracts were determine by Inductively Coupled Plasma-source Optical Emission Spectroscopy, and $\mathrm{Cd}, \mathrm{Cr}$, and $\mathrm{Pb}$ were determined by flame atomic absorption spectroscopy.

\subsection{Synthetic root exudates for metal extraction}

The total amount of plant available metals in biosolids-amended soils, $C_{0}$ in Eq (1), may be estimated by extracting the soils using a mixture of organic acids that mimic the composition and strength of organic acids found in the rhizosphere of plants grown on biosolids-amended medium and has the chemical matrix and ionic strength of the soil solution. A synthetic root exudate solution was formulated based on the organic acids recovered from the rhizosphere of corn grown on biosolids-amended media from seedling to maturity (Koo et al., 2006). The extracting solution consists of $0.01 \mathrm{M}$ organic acids mixture $\left(\mathrm{COO}^{-}\right)$in $13.5 \mathrm{mM} \mathrm{Ca}$ $\left(\mathrm{NO}_{3}\right)_{2}$ with a $\mathrm{pH}$ of 4.8

For the laboratory extraction, aliquots of ten-gram soil samples were mixed with $10 \mathrm{~mL}$ of synthetic organic acid mixtures in $50 \mathrm{~mL}$ Teflon test tubes. The mixtures were allowed to equilibrate at $25^{\circ} \mathrm{C}$ using the rotary mixer at approximately $1 \mathrm{rpm}$ for $48 \mathrm{~h}$. One $\mathrm{mL}$ of chloroform was added to each test tube to prevent microbial decomposition of organic acid mixtures during the course of the equilibration. After $48 \mathrm{~h}$, the extraction approaches the equilibrium, the spent extracting solution was decanted and fresh synthetic solution was added to extract additional metals. The extractions were repeated for 10 times.

\section{Results and discussion}

\subsection{Total phytoavailable metal pool}

The soil samples representing field conditions when biosolids applications ceased were extracted by the synthetic root exudates to determine the total phytoavailable metal content, $C_{0}$, as shown in Equations (1) and (2). Typically, one extraction does not recover all of the metals in the extractable fraction. Fig. 1 shows one example of the outcome of the successive extractions. While 10 successive extractions did not remove all of the extractable metals (no obvious plateau reached), the total organic acid extractable metal which represents the capacity factor of the phytoavailability model can be well projected from Eq. (3).

Table 1 summarizes the estimated plant available metal pool $\left(C_{0}\right)$ and its percentage of the total metal content of biosolids-

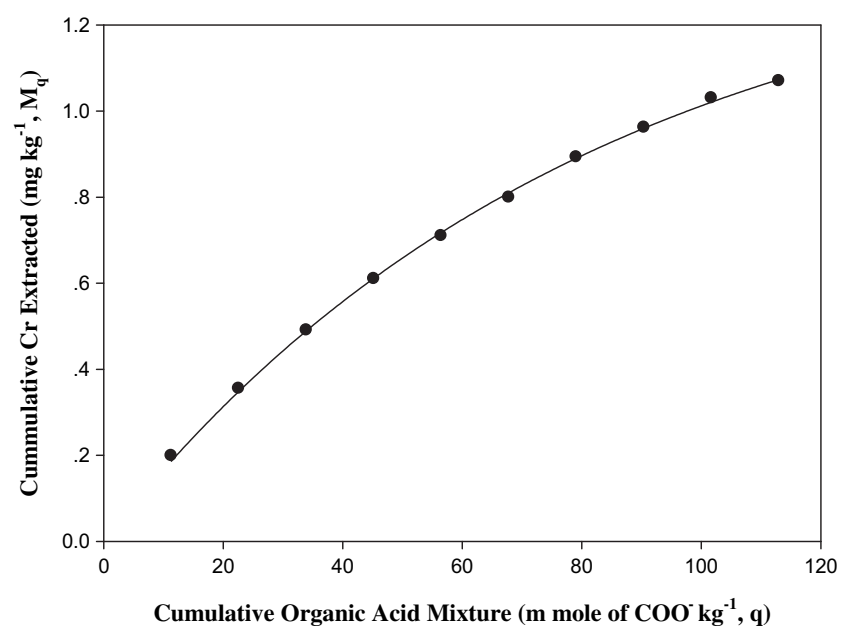

Fig. 1. Cumulative $\mathrm{Cr}$ extracted with successive synthetic organic acid mixture from the biosolids-treated Chicago soil (Field 19). Data were fitted to Eq. (3).
Table 1

Estimated plant available metal pool $\mathrm{C}_{0}$ based on the successive extraction and its percentage of the total metal of biosolids-amended soils at different field sites.

\begin{tabular}{|c|c|c|c|c|}
\hline Field & Element & $\begin{array}{l}\text { Concentration } \\
\text { total }\left(\mathrm{mg} \mathrm{kg}^{-1}\right)\end{array}$ & $\begin{array}{l}\text { Estimated } C_{0} \\
\left(\mathrm{mg} \mathrm{kg}^{-1}\right)\end{array}$ & $\%$ of total \\
\hline \multirow[t]{6}{*}{ MWRDGC Field 19} & $\mathrm{Cd}$ & 109 & 42.7 & 39 \\
\hline & $\mathrm{Cr}$ & 745 & 1.62 & 0.22 \\
\hline & $\mathrm{Cu}$ & 321 & 35.5 & 11 \\
\hline & $\mathrm{Ni}$ & 86 & 36.1 & 42 \\
\hline & $\mathrm{Pb}$ & 201 & 3.44 & 1.7 \\
\hline & $\mathrm{Zn}$ & 749 & 372 & 50 \\
\hline \multirow[t]{6}{*}{ MWRDGC Field 21} & $\mathrm{Cd}$ & 82 & 30.9 & 38 \\
\hline & $\mathrm{Cr}$ & 588 & 1.16 & 0.20 \\
\hline & $\mathrm{Cu}$ & 231 & 29.9 & 13 \\
\hline & $\mathrm{Ni}$ & 73.3 & 33.5 & 46 \\
\hline & $\mathrm{Pb}$ & 174 & 2.38 & 1.4 \\
\hline & $\mathrm{Zn}$ & 616 & 299 & 49 \\
\hline \multirow[t]{6}{*}{ MWRDGC Field 23} & $\mathrm{Cd}$ & 70 & 21.8 & 31 \\
\hline & $\mathrm{Cr}$ & 563 & 0.70 & 0.12 \\
\hline & $\mathrm{Cu}$ & 182 & 22.9 & 13 \\
\hline & $\mathrm{Ni}$ & 65.8 & 28.5 & 43 \\
\hline & $\mathrm{Pb}$ & 110 & 1.28 & 1.2 \\
\hline & $\mathrm{Zn}$ & 516 & 275 & 53 \\
\hline \multirow[t]{6}{*}{ UM Low } & $\mathrm{Cd}$ & 4.8 & 1.07 & 22 \\
\hline & $\mathrm{Cr}$ & 41 & 0.68 & 1.6 \\
\hline & $\mathrm{Cu}$ & 49 & 3.73 & 7.6 \\
\hline & $\mathrm{Ni}$ & 17 & 4.26 & 25 \\
\hline & $\mathrm{Pb}$ & 33 & 0.68 & 2.1 \\
\hline & $\mathrm{Zn}$ & 71 & 30.7 & 43 \\
\hline \multirow[t]{6}{*}{ UM Medium } & $\mathrm{Cd}$ & 13 & 2.76 & 21 \\
\hline & $\mathrm{Cr}$ & 80 & 1.13 & 1.4 \\
\hline & $\mathrm{Cu}$ & 100 & 9.56 & 9.6 \\
\hline & $\mathrm{Ni}$ & 47 & 14.3 & 30 \\
\hline & $\mathrm{Pb}$ & 46 & 0.99 & 2.1 \\
\hline & $\mathrm{Zn}$ & 152 & 68.1 & 45 \\
\hline \multirow[t]{6}{*}{ UM High } & $\mathrm{Cd}$ & 16 & 3.70 & 24 \\
\hline & $\mathrm{Cr}$ & 87 & 1.72 & 2.0 \\
\hline & $\mathrm{Cu}$ & 112 & 14.9 & 13 \\
\hline & $\mathrm{Ni}$ & 60 & 23.4 & 29 \\
\hline & $\mathrm{Pb}$ & 48 & 1.59 & 3.3 \\
\hline & $\mathrm{Zn}$ & 207 & 97.3 & 47 \\
\hline
\end{tabular}

amended soils at the two field sites. At the MWRDGC sites, the plant availability of metals of fields at each site was comparable as they received the biosolids from the same source. About $31-39 \%$, $0.1-0.2 \%, 11-13 \%, 42-46 \%, 1.2-1.7 \%$, and $49-53 \%$ of the total $\mathrm{Cd}, \mathrm{Cr}$, $\mathrm{Cu}, \mathrm{Ni}, \mathrm{Pb}$, and $\mathrm{Zn}$ in the receiving soils, respectively was available at the beginning of the testing period, namely, 1984. Judging by the narrow range, the percentages of plant available metals in each MWRDGC receiving field were comparable at the time of termination of biosolids application. The availability however varied greatly between the elements. For example, approximately $0.2 \%$ of the $\mathrm{Cr}$ in receiving soils would be available while $50 \%$ plus of the total $\mathrm{Zn}$ in the receiving soils was available. The plant availability of metals in biosolids-amended soil follows a descending order of $\mathrm{Zn}>\mathrm{Ni}>\mathrm{Cd}>\mathrm{Cu}>\mathrm{Pb}>\mathrm{Cr}$. Among them, the availabilities of $\mathrm{Cd}$, $\mathrm{Ni}$, and $\mathrm{Zn}$ were comparable and were much higher than the others.

At UM, the metal capacity factors $\left(C_{0}\right)$ of the receiving soils determined according to the successive extraction protocol and Equation (3) were 21 to $24,1.4$ to $2.0,7.6$ to 13,25 to $30,2.1$ to 3.3 , and 43 to $47 \%$ of the total $\mathrm{Cd}, \mathrm{Cr}, \mathrm{Cu}, \mathrm{Ni}, \mathrm{Pb}$, and $\mathrm{Zn}$ in the receiving soils, respectively, at the beginning of the testing period (i.e. 1978). The patterns for plant available metals at this site were similar to those at MWRDGC. The specific percentages of available metal in each receiving soil however were not alike reflecting the local specific conditions. It was noted that the available metals were proportionally increased as amount of applied biosolids increased. 


\subsection{Field-determined metal removal rate}

The plant available metal pool of the receiving soils should gradually decrease from its initial size, $C_{0}$, with the annual crop harvest. The metal uptake of crops at each field was tracked for 12 years at MWRDGC and 7 years at UM. At MWRDGC, 12 corn harvests cumulatively removed 1.85 to $2.25,4.3$ to $4.5,0.7$ to 1.0 , and 45 to $50 \mathrm{~kg} \mathrm{ha}^{-1}$ of $\mathrm{Cd}, \mathrm{Cu}, \mathrm{Ni}$, and $\mathrm{Zn}$, respectively. The concentrations of $\mathrm{Cr}$ and $\mathrm{Pb}$ in harvested plant tissues were negligible and the recoveries by crop harvests were therefore not calculated. On average, 12 years of continuous harvests removed $1.33 \%, 0.42 \%, 0.46 \%$ and $2.50 \%$ of the cumulative biosolids loads of $\mathrm{Cd}, \mathrm{Cu}, \mathrm{Ni}$ and $\mathrm{Zn}$, respectively. Fig. 2 depicts the cumulative metal uptake by corn for field 19, 21, and 23 at MWRDGC from 1984, the year biosolids applications were terminated, through 1997. The year by year annual changes in the metal uptake by plants were slight. Overall, the cumulative recoveries of available metals exhibited the exponential trend of Equation (2). The data fitted better with the exponential regression than the linear regression. It would take a long period to deplete the available metal pool.

Since the data were far from reaching the plateau, it is impossible to obtain the $C_{0}$ and $k$ simultaneously based on the field data. Therefore, we used the laboratorial determined $C_{0}$ (Table 1 ) to fit the field data according to Equation (2) to obtain the metal uptake rate constant, $k$. The duration for removing $50 \%$ of metal in the plant available pool can be estimated as: $t_{0.50}=0.693 / k$. The $k$ and the calculated $t_{1 / 2}$ for the three fields at the MWRDGC are summarized in Table 2. Under these specific field conditions, it will require 141 to 178,158 to 187,546 to 597 , and 147 to 158 years of cultivation to remove $50 \%$ of the plant available pool of $\mathrm{Cd}, \mathrm{Cu}, \mathrm{Ni}$, and $\mathrm{Zn}$ respectively by plant harvests. These data may not exactly meet with the realistic field conditions. But, it does reveal the long-term phytoavailability of these metals in the biosolids-amended soils.

The plant uptake of metals for the biosolids-amended fields at UM was evaluated in the same manner. The cumulative metal uptake by corn from 1978 through 1984 was grouped according to the biosolids loading from 1978 through 1984 into control, low,

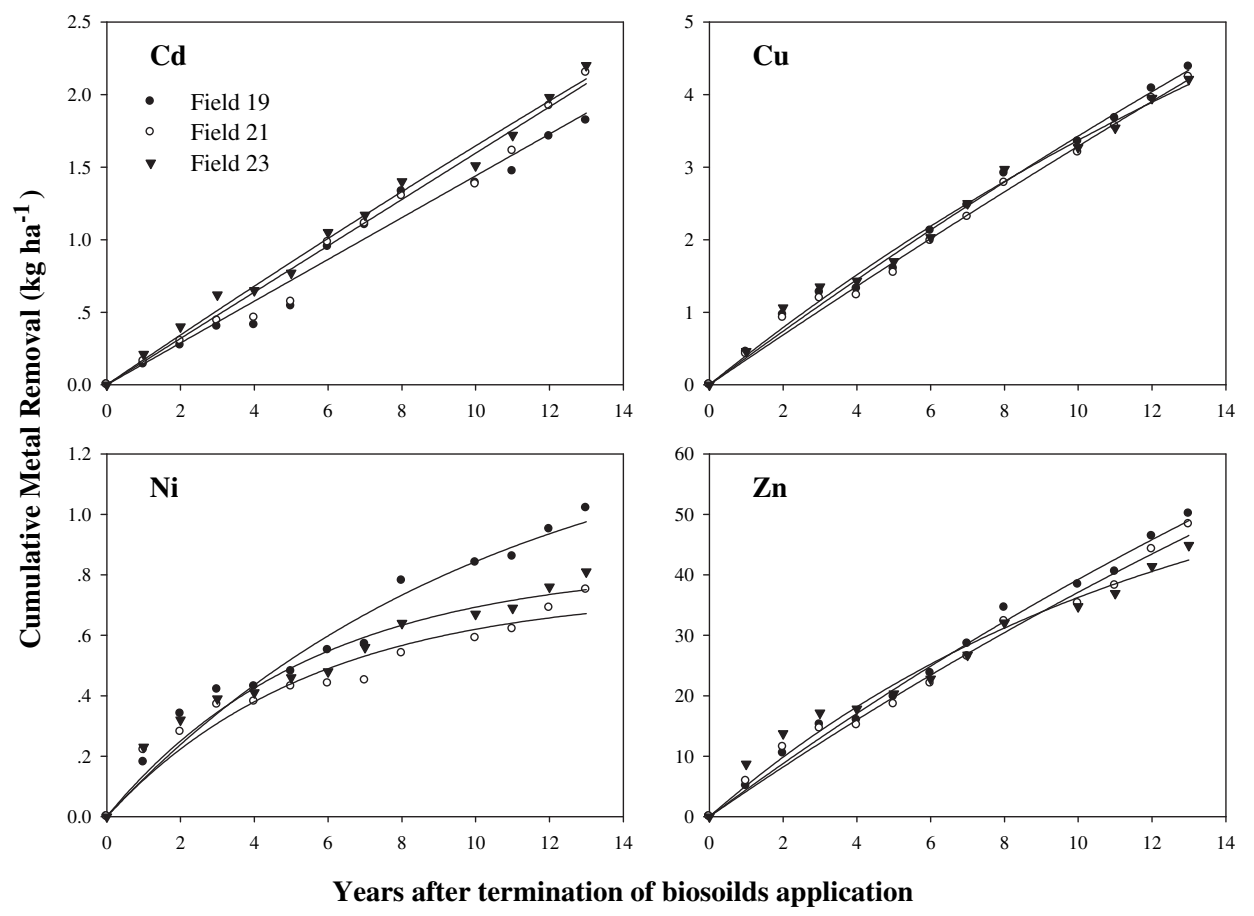

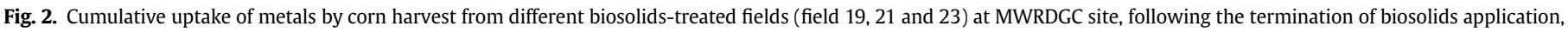
data were fitted to Eq. (2). medium and high that represented no biosolids input, $60 \mathrm{Mg} \mathrm{ha}^{-1}$, $120 \mathrm{Mg} \mathrm{ha}^{-1}$, and $180 \mathrm{Mg} \mathrm{ha}^{-1}$ treatment levels (Fig. 3). In 7 years of corn harvests, the metals recovered increased incrementally from 0.11 to $0.36,0.049$ to $0.058,0.39$ to $0.48,0.073$ to $0.089,0.11$ to 0.14 , and 5.7 to $10.1 \mathrm{~kg} \mathrm{ha}^{-1}$ of $\mathrm{Cd}, \mathrm{Cr} \mathrm{Cu}, \mathrm{Ni}, \mathrm{Pb}$ and $\mathrm{Zn}$, respectively according to the biosolids treatment levels. On average, $1.27 \%$, $0.07 \%, 0.63 \%, 0.32 \%, 0.14 \%$ and $3.94 \%$ of the $\mathrm{Cd}, \mathrm{Cr} \mathrm{Cu}, \mathrm{Ni}, \mathrm{Pb}$ and $\mathrm{Zn}$ in the receiving soils, respectively were recovered. Similarly, the data and their corresponding $C_{0}$ were fitted to Equation (2) to obtain $k$ and $t_{1 / 2}$ for the three biosolids treatment levels at UM (Table 2). The estimated times to remove half of the plant available metal pools for the biosolids receiving soils at UM were 124 to 142 , 150 to 214,90 to 155,586 to 703,113 to 177 , and 82 to 89 years for $\mathrm{Cd}, \mathrm{Cr}, \mathrm{Cu}, \mathrm{Ni}, \mathrm{Pb}$, and $\mathrm{Zn}$, respectively. In comparison with the MWRDGC site, the estimated plant metal removal rates were generally higher, thus took fewer years to remove half of the plant available metal pools.

\subsection{Effective annual organic acids production factor of rhizosphere, $A$}

Under realistic conditions, the field based metal uptake rate constant, $k$ (i.e. Equations (1) and (2)) is unknown and must be estimated through the metal dissolution rate constant of laboratory extractions, $b$ (i.e. Equation (3)) via the effective annual organic acid production factor of the rhizosphere, $A$. The $A$ for each metal at the testing fields of MWRDGC and UM were calculated based on Equation (5). The ranges of the $A$ for biosolids-amended soils at MWRDGC were $0.70-78,0.48-0.58,0.42-0.70$, and 0.60-0.92 mol $\mathrm{COO}^{-} \mathrm{kg}^{-1} \mathrm{yr}^{-1}$ for $\mathrm{Cd}, \mathrm{Cr}, \mathrm{Cu}, \mathrm{Ni}, \mathrm{Pb}$, and $\mathrm{Zn}$, respectively. For the biosolids-receiving soils at $\mathrm{UM}$, the $A$ ranges were $0.58-7.0,0.44-1.08,0.44-0.80,0.70-0.96,0.92-1.02$, and 0.76-1.21 (m-mole $\mathrm{COO}^{-} \mathrm{kg}^{-1} \mathrm{yr}^{-1}$ ) for $\mathrm{Cd}, \mathrm{Cr}, \mathrm{Cu}, \mathrm{Ni}, \mathrm{Pb}$, and $\mathrm{Zn}$, respectively. For a given location, the range of the $A$ for a metal was not significantly different $(p>0.05)$. When the data were pooled, the statistical inference indicated that the difference due to elements were not significantly different $(p>0.05)$. The data for all 
Table 2

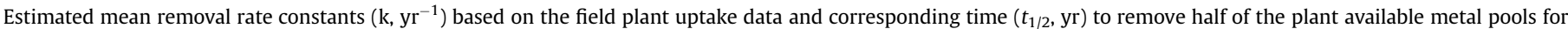
biosolids-treated soils at different field sites.

\begin{tabular}{|c|c|c|c|c|c|c|c|c|c|c|c|c|}
\hline \multirow[t]{2}{*}{ Case } & \multicolumn{2}{|l|}{$\mathrm{Cd}$} & \multicolumn{2}{|l|}{$\mathrm{Cr}$} & \multicolumn{2}{|l|}{$\mathrm{Cu}$} & \multicolumn{2}{|l|}{$\mathrm{Ni}$} & \multicolumn{2}{|l|}{$\mathrm{Pb}$} & \multicolumn{2}{|l|}{$\mathrm{Zn}$} \\
\hline & $k$ & $t_{1 / 2}$ & $k$ & $t_{1 / 2}$ & $k$ & $t_{1 / 2}$ & $k$ & $t_{1 / 2}$ & $k$ & $t_{1 / 2}$ & $k$ & $t_{1 / 2}$ \\
\hline MWRDGC Field\#19 & 0.0039 & 178 & - & - & 0.0044 & 158 & 0.0013 & 546 & - & - & 0.0046 & 151 \\
\hline MWRDGC Field\#21 & 0.0041 & 169 & - & - & 0.0037 & 187 & 0.0012 & 597 & - & - & 0.0047 & 147 \\
\hline MWRDGC Field\#23 & 0.0049 & 141 & - & - & 0.0037 & 187 & 0.0012 & 559 & - & - & 0.0044 & 158 \\
\hline UM Low & 0.0053 & 130 & 0.0040 & 171 & 0.0077 & 90 & 0.0012 & 586 & 0.0062 & 113 & 0.0085 & 82 \\
\hline UM Medium & 0.0056 & 124 & 0.0046 & 150 & 0.0061 & 114 & 0.0010 & 703 & 0.0062 & 113 & 0.0081 & 86 \\
\hline UM High & 0.0049 & 142 & 0.0032 & 214 & 0.0045 & 155 & 0.0010 & 680 & 0.0039 & 177 & 0.0077 & 89 \\
\hline
\end{tabular}

elements were then pooled to test for differences between the soils MWRDGC and UM and the results indicated that the effective rhizosphere organic acid production factors, $A$, were not significantly different between the two locations. It appeared that $A$ was not affected by the metal elements and the soils (i.e. location). For a plant species, in this case corn, A may be treated as a constant.

The entire population of $A$ (168 observations), according to the outcome of the Kolmogorov-Smirnov test, follows a normal distribution with mean $=0.76$, standard deviation $=0.24$, and variance $=0.29$. The distribution of the effective annual rhizosphere organic acid production (A) is illustrated in Fig. 4. The cumulative probability distribution can be predicted based on the mean, $x_{0}$ and standard deviation, $\sigma$, of the samples as:

$F(x)=0.5+0.5 \times \operatorname{erf}\left(\frac{\left(x-x_{0}\right)}{\sigma \sqrt{2}}\right)$

where $F(x)$ denotes the probability that $A \leq x$ and erf denotes the error function Based on the probability distribution function, the uncertainty associated with estimating plant availability of metals due to the $A$ value may be expressed. For example: Where $A=1.2 \mathrm{~m}$-mole $\mathrm{COO}^{-} \mathrm{kg}^{-1} \mathrm{yr}^{-1}$, there is $96.6 \%$ probability
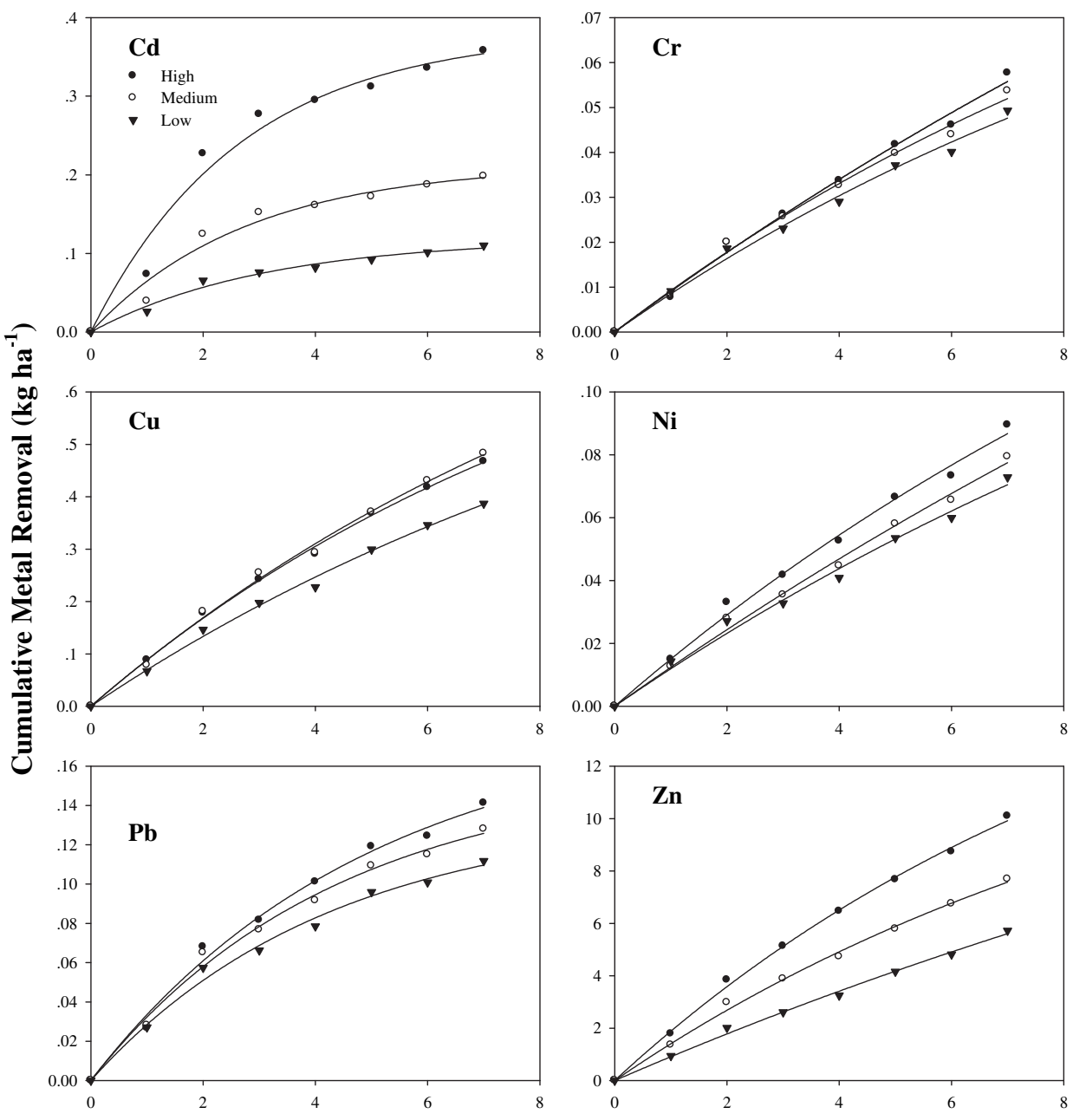

Year after termination of biosolids application

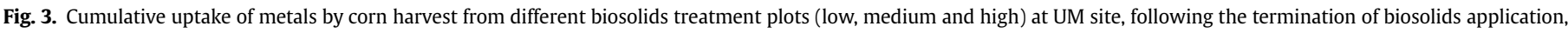
data were fitted to Eq. (2). 


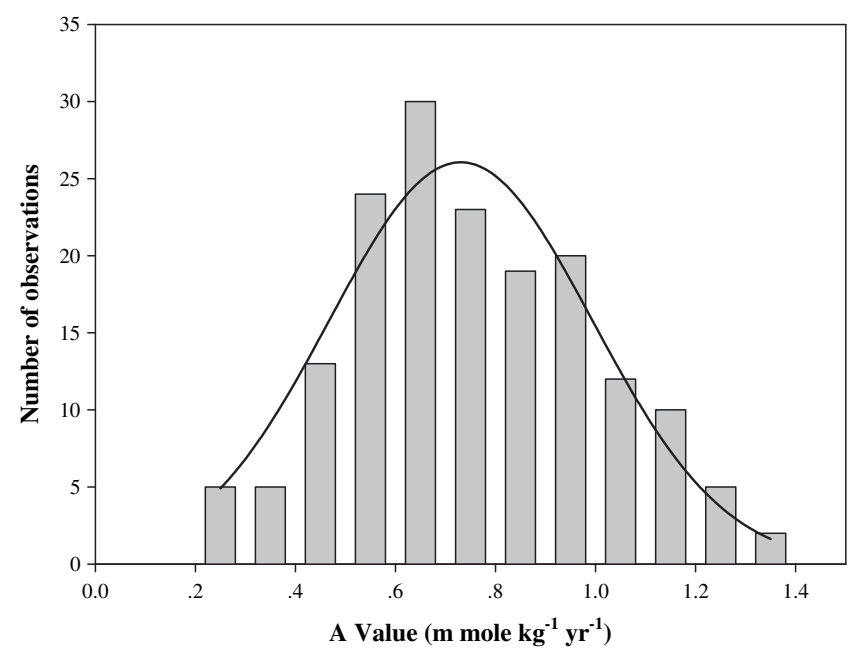

Fig. 4. Distribution of the effective annual organic acid production (A) of the rhizosphere of corn.

according to the probability density function (Fig. 4) that the $k$ will be equal to or less than $0.012 \mathrm{yr}^{-1}$, assuming a laboratory determination of the successive extraction trace element release rate constant, $b=0.01 \mathrm{~kg}$ soil per m-mole of $\mathrm{COO}^{-}$. Consequently, there is $96.6 \%$ probability that $50 \%$ of the plant available metal would be removed from the receiving soil in 58 years. As corn was the crop at both testing sites, the specificity of the $A$ value needs to be tested and confirmed in future studies on other plant species.

\section{Conclusion}

In cropland soils, the majority of the indigenous and introduced metals are associated with the solid phases. Root exudates play important roles in dissolving the metals and making them available for plant uptake. We proposed a model to assess the long-term availability of metals to plants grown in biosolids-amended soils. The metal removal $\left(\mathrm{kg} \mathrm{ha}^{-1}\right)$ from biosolids-amended soils by plants can be evaluated based on two parameters $C_{0}$ and $\mathrm{k}$. The total plant available metal pool of a biosolids-amended soil, $C_{0}$, can be determined by successively extracting the soil with a synthetic rhizosphere organic acid mixture and fitting to an exponential decay model. The field metal release rate constant, $k$, may be evaluated by the metal dissolution rate constant of laboratory based successive extractions, $b$, and the effective rhizosphere organic acid production factor, $A$, which is a plant specific constant. These two parameters were examined for biosolids-amended soils at two long-term biosolids land application sites. The results predicted the long-term phytoavailability of biosolids-borne metals. The proposed model concept and methods can be used to evaluate the availability of metals in biosolids-amended soils and to estimate the effectiveness of remediation by plants.

\section{Acknowledgements}

The research was supported by the Water Environmental Research Foundation (WERF-97-REM-5) and U.S. Department of Agriculture CSRS Regional Research Project (W-170).

\section{List of parameters}

the amounts of metal removed by crops at time $t\left(\mathrm{mg} \mathrm{kg}^{-1}\right.$ soil)
$M_{C} \quad$ the cumulative metal removal by the plant harvests ( $\mathrm{mg} \mathrm{kg}^{-1}$ soil)

$C_{0} \quad$ the plant available metal pool of the biosolids-amended soils ( $\mathrm{mg} \mathrm{kg}^{-1}$ soil)

$k \quad$ the field plant removal rate $\left(\right.$ year $^{-1}$ )

$a$ the total extractable metal by the synthetic organic acid solution $\left(\mathrm{mg} \mathrm{kg}^{-1}\right)$

$q \quad$ volumes of synthetic organic acid used ( $\mathrm{m}$ mole of $\mathrm{COO}^{-}$ $\mathrm{kg}^{-1}$ soil)

$b$ metal release rate based on the successive extraction

$A$ the effective annual rhizosphere organic acids production factor (mole $\mathrm{COO}^{-} \mathrm{kg}^{-1} \mathrm{yr}^{-1}$ )

$t_{0.50}$ the duration for removing $50 \%$ of metal in the plant available pool (year)

\section{References}

Awad, F., Romheld, V., Marschner, H., 1994. Effect of root exudates on mobilization in the rhizosphere and uptake of iron by wheat plants. Plant and Soil 165 , 213-218.

Brown, S.L., Chaney, R.L., Lloyd, C.A., Angle, J.S., Ryan, J.A., 1996. Relative uptake of cadmium by garden vegetables and fruits grown on long-term biosolidamended soils. Environmental Science and Technology 30, 3508-3511.

Candelaria, L.M., Chang, A.C., 1997. Cadmium activities, solution speciation, and solid phase distribution of $\mathrm{Cd}$ in cadmium nitrate and sewage sludge-treated soil systems. Soil Science $162,722-732$.

Chaignon, V., Quesnoit, M., Hinsinger, P., 2009. Copper availability and bioavailability are controlled by rhizosphere $\mathrm{pH}$ in rape grown in an acidic $\mathrm{Cu}$ contaminated soil. Environmental Pollution 157, 3363-3369.

Chen, W.P., Chang, A.C., Wu, L., Zhang, Y., 2008. Metal uptake by corn grown on media treated with particle-size fractionated biosolids. Science of the Total Environment 392, 166-173.

Chen, Y.X., Lin, Q., Luo, Y.M., He, Y.F., Zhen, S.J., Yu, Y.L., Tian, G.M., Wong, M.H., 2003. The role of citric acid on the phytoremediation of heavy metal contaminated soil. Chemosphere 50, 807-811.

Dowdy, R.H., Latterell, J.J., Hinesly, T.D., Grossman, R.B., Sullivan, D.L., 1991. Tracemetal movement in an aeric Ochraqualf following 14 years of annual sludge applications. Journal of Environmental Quality 20, 119-123.

Feng, M.H., Shan, X.Q., Zhang, S., Wen, B., 2005. A comparison of the rhizospherebased method with DTPA, EDTA, CaCl2, and NaNO3 extraction methods for prediction of bioavailability of metals in soil to barley. Environmental Pollution 137, 231-240.

Gao, Y., He, J., Ling, W., Hu, H., Liu, F., 2003. Effects of organic acids on copper and cadmium desorption from contaminated soils. Environmental International 29, 613-618.

Guerra, P., Ahumada, I., Carrasco, A., 2007. Effect of biosolid incorporation to mollisol soils on $\mathrm{Cr}, \mathrm{Cu}, \mathrm{Ni}, \mathrm{Pb}$, and $\mathrm{Zn}$ fractionation, and relationship with their bioavailability. Chemosphere 68, 2021-2027.

Hinsinger, P., 1998. How do plant roots acquire mineral nutrients? Chemical processes involved in the rhizosphere. Advances in Agronomy 64, 225-265.

Hu, Z.Y., Zhu, Y.G., Li, M., Zhang, L.G., Cao, Z.H., Smith, F.A., 2007. Sulfur (S)-induced enhancement of iron plaque formation in the rhizosphere reduces arsenic accumulation in rice (Oryza sativa L.) seedlings. Environmental Pollution 147, 387-393.

Kim, B., McBride, M.B., 2006. A test of sequential extractions for determining metal speciation in sewage sludge-amended soils. Environmental Pollution 144, 475-482.

Koo, B.J., Chang, A.C., Crowley, D.E., Page, A.L., 2006. Characterization of organic acids recovered from rhizosphere of corn grown on biosolids treated media. Communications in Soil Science and Plant Analysis 37, 871-887.

Krishnamurti, G.S.R., Cieslinski, G., Huang, P.M., Van Rees, K.C.J., 1997. Kinetics of cadmium release from soils as influenced by organic acids: implication in cadmium availability. Journal of Environmental Quality 26, 271-277.

Laheurte, F., Leyval, K.C.J., Berthelin, J., 1990. Root exudates of maize, pine and beech seedlings influenced by mycorrhizal and bacterial inoculation. Symbiosis 9, 111-116.

Luo, C.L., Shen, Z.G., Li, X.D., 2008. Root exudates increase metal accumulation in mixed cultures: implications for naturally enhanced phytoextraction. Water Air and Soil Pollution 193, 147-154.

McBride, M.B., Richards, K., Steenhuis, T., 2004. Bioavailability and crop uptake of trace elements in soil columns amended with sewage sludge products. Plant and Soil 262, 71-84.

McGrath, S.P., Zhao, F.J., Dunham, S.J., Crosland, A.T., Coleman, K., 2000. Long term changes in the extractability and bioavailability of zinc and cadmium after sludge application. Journal of Environmental Quality 29, 875-883.

Mench, M., Martin, E., 1991. Mobilization of cadmium and other metals from two soils by root exudates of Zea mays L., Nicotiana tabacum L. and Nicotiana rustica L. Plant and Soil 132, 187-196.

Menzies, N.W., Donn, M.J., Kopittke, P.M., 2007. Evaluation of extractants for estimation of the phytoavailable trace metals in soils. Environmental Pollution 145, 121-130. 
O'Connor, G.A., 1988. Use and misuse of DTPA soil tests. Journal of Environmental Quality 17, 715-718

Philippe, H., Plassard, C., Jaillard, B., 2006. Rhizosphere: a new frontier for soil biogeochemistry. Journal of Geochemical Exploration 88, 210-213.

Pietz, R.I., Peterson, J.R., Hinsely, T.D., Ziegler, E.L., Redborg, K.E., Lue-Hing, C., 1982. Sewage sludge application to calcareous strip-mine spoil: I. Effect on corn yields and $\mathrm{N}, \mathrm{P}, \mathrm{K}, \mathrm{Ca}$, and $\mathrm{Mg}$ compositions. Journal of Environmental Quality 11, $685-689$.

Pomilio, A.B., Leicach, S.R., Grass, M.Y., Ghersa, C.M., Santoro, M., Vitale, A.A., 2000 Constituents of the root exudates of Avena fatua grown under far-Infraredenriched light. Phytochemical Analysis 11, 304-308.
Tao, S., Chen, Y.J., Xu, F.L., Gao, J., Li, B.G., 2003. Changes of copper speciation in maize rhizosphere soil. Environmental Pollution 122, 447-454.

Torri, S., Lavadoa, R., 2009. Plant absorption of trace elements in sludge amended soils and correlation with soil chemical speciation. Journal of Hazardous Materials 166, 1459-1465.

Veeken, A.H.M., Hamelers, H.V.M., 1999. Removal of heavy metals from sewage sludge by extraction with organic acids. Water Science and Technology 40, 129-136.

Wang, P., Shan, X.Q., Zhang, S.Z., Wen, B., 2004. A model for evaluation of the phytoavailability of trace elements to vegetables under the field conditions. Chemosphere 55, 811-822. 